\title{
Climate change and ecosystems of the Mid-Atlantic Region
}

\author{
Catriona E. Rogers ${ }^{1, *}$, J ohn P. M cC arty ${ }^{2,3}$ \\ ${ }^{1} \mathrm{~N}$ ational Center for Environmental Assessment, US Environmental Protection Agency (EPA), Washington, DC 20460, USA \\ ${ }^{2}$ AAAS Science and Engineering Fellow, US EPA, Washington, DC 20460, USA \\ ${ }^{3}$ Biology Department, University of M aryland, College Park, Maryland 20742, USA
}

\begin{abstract}
This paper discusses the current status of forested, wetland, freshwater and coastal ecosystems; the combined impacts of habitat alteration, pollution and non-native invasive species on those systems; how climatic changes could interact with existing stresses; potential management strategies, and crucial research gaps. Changes in climate and climate variability would significantly affect natural ecosystems, and may pose additional threats to the already-stressed ecosystems of the MidAtlantic Region (MAR). Fragmentation of the MAR's forests may hinder the migration of some species. Urban development and wetland losses leave the MAR's rivers and streams and near-shore areas vulnerable to damages if the frequency and intensity of storms increase. Inputs of sediments, nutrients and toxic chemicals to streams, lakes and estuaries might increase if precipitation increases. Accelerated sea-level rise could accelerate the loss of coastal wetlands. Estuaries are sensitive to changes in temperature, salinity and nutrient loads, and could be adversely affected by projected climatic changes. Populations of rare, native species could decline, while problems with non-native invasive species, such as kudzu and gypsy moths, might increase. The best strategies to protect ecosystems from climatic changes may be those that reduce other stresses, thus increasing resilience to a variety of stresses. Societal priorities for ecosystem protection need to be articulated, and research is needed into the values of ecosystems, ecosystem functioning, human impacts, long-term ecological monitoring, and management options to provide a basis for selecting effective measures.
\end{abstract}

KEY WORDS: Ecosystems - Societal values - Climate change - Mid-Atlantic Regional Assessment . Ecological

\section{INTRODUCTION}

Human activities alter the dynamics within ecosystems, 'interacting systems of biological communities and their non-living surroundings' (US Environmental Protection Agency [EPA] 1999), resulting in changes of societal concern. This paper focuses on ecosystems of the Mid-Atlantic Region (MAR), and addresses 4 questions that guide the National Assessment process $^{1}$ : (1) What is the status of resources and what are the current stresses? (2) How might changes in climate and climate variability exacerbate or ameliorate current conditions? (3) What are the potential strategies

*E-mail: rogers.catriona@epa.gov

${ }^{1}$ The National Assessment, which is being conducted by the US Global Change Research Program, is mandated by the Global Change Research Act of 1990. For further information, see www.usgcrp.gov for coping with risk and taking advantage of new opportunities? and (4) What are the policy-relevant research gaps? Other papers in this Special focus on forestry (M cKenney-Easterling et al. 2000), coastal systems (Najjar et al. 2000), agriculture (Abler \& Shortle 2000) and human health (Benson et al. 2000). While issues treated in these papers are relevant here, to avoid redundancy, they are not treated in depth in this paper. Cities and farms, important ecosystems in their own right, are discussed primarily in terms of how they affect other ecosystems, such as forests, wetlands, freshwaters, and coastal ecosystems.

Underlying our approach in this paper is the question: What aspects of ecosystems are important to people in the MAR? Unfortunately, our understanding of how people depend upon ecosystems and how people value different aspects of ecosystems is very incomplete. Based on currently available information, we 
emphasize aspects of ecosystems that we believe are important to residents of the MAR. Previous workshops (Climate Institute 1996a,b, Fisher et al. 1997, US National Assessment 1997) provided useful guidance in identifying issues of concern.

\section{WHAT IS THE STATUS OF MID-ATLANTIC ECOSYSTEMS AND WHAT ARE THE CURRENT STRESSES ON THOSE SYSTEM S?}

The MAR (Fig. 1), with its mountains, valleys and coastal plains, exhibits tremendous physical and ecological diversity (J ones et al. 1997). The lowlands of the Coastal Plain are characterized by estuaries, including the Chesapeake and Delaware Bays, and coastal wetlands. Despite its dense population, the Piedmont still contains significant natural communities. The relatively rich soils and moderate climate of this region historically supported large expanses of deciduous forest but also made the land valuable for agriculture. To the west and north lie the Ridge and Valley System of the

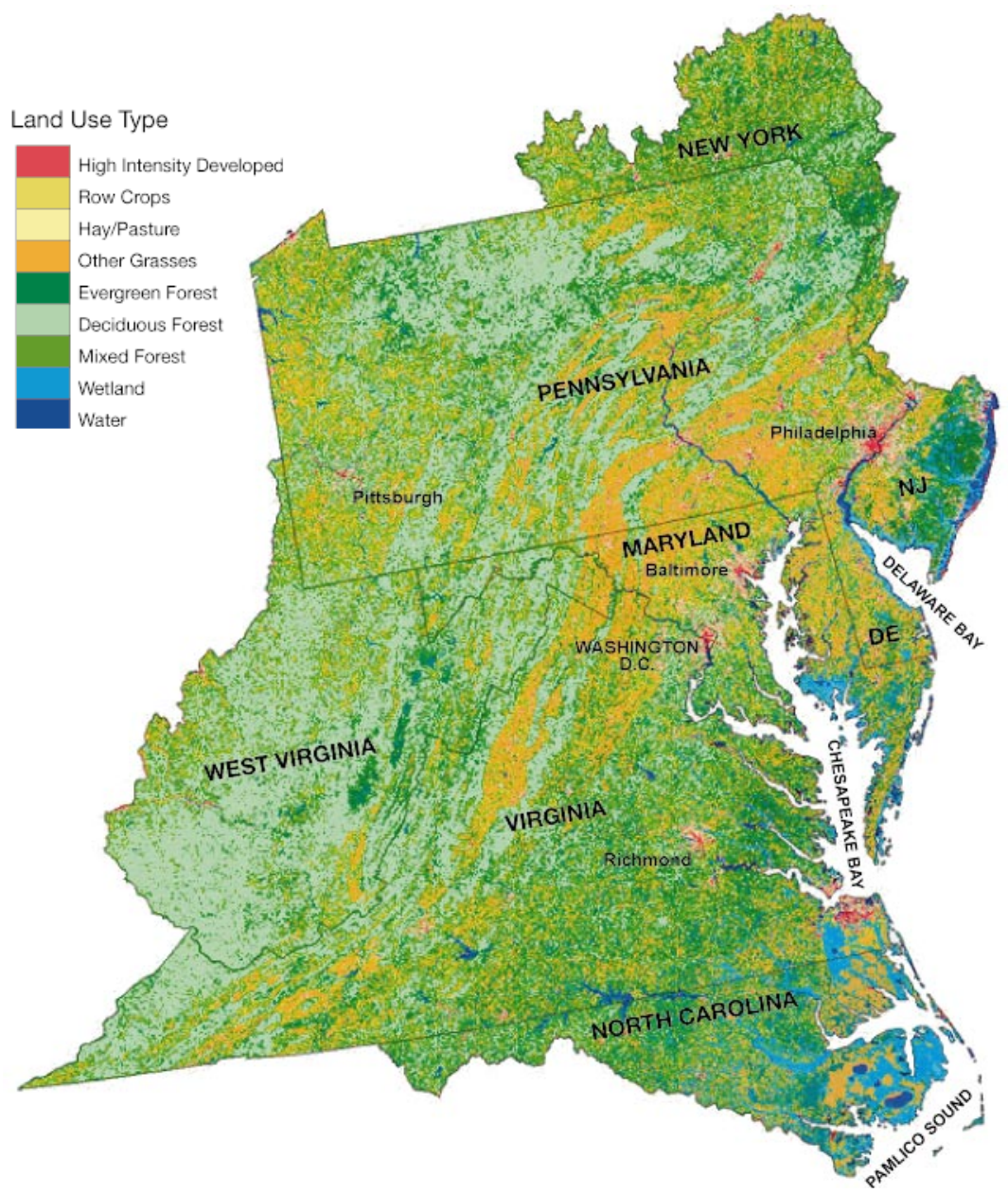

A ppalachian Mountains and the Appalachian Plateau regions with their diverse forest communities and numerous, meandering streams and rivers. The ecological diversity of the MAR is in part a function of the large variations in topography, soils, and climate within the MAR.

Prior to European settlement, forests covered about $95 \%$ of the MAR. Peak deforestation occurred in the mid-1800s, followed by substantial reforestation of agricultural lands in the last $100 \mathrm{yr}$, and followed most recently by a slow loss of forests to urban development (McKenney-Easterling et al. 2000). Forests currently cover $65 \%$ of the MAR; agriculture, wetlands and urban lands cover most of the rest, 25, 4, and 4\%, respectively (Polsky et al. 2000, in this issue). Agriculture is unevenly distributed: more than $70 \%$ of the Delmarva Peninsula is cleared, while parts of West Virginia and western Virginia remain more than 97\% forested (J ones et al. 1997). Human population is also unevenly distributed: the highest population densities occur along the urban corridor from Richmond VA, through Washington, DC, Baltimore MD, and Philadelphia PA, as well as in the Pittsburgh metropolitan area. During the past $30 \mathrm{yr}$, human population in the region increased at approximately $0.7 \% \mathrm{yr}^{-1}$, with higher rates in northern Virginia and the Delmarva Peninsula and low or negative growth rates in much of the western half of the M AR (V ones et al. 1997).

\subsection{Forested ecosystems}

In addition to the direct economic value of forest products (Rose et al. 2000, in this issue), forests al so provide habitat for wild life and play important roles in the cycling of water and nutrients in ecosystems (Daily et al. 1997). Public natural areas provide recreational opportunities and protect important communities and species. State and $\mathrm{Na}$ tional Forests in Pennsylvania, West Virginia and Virginia provide some of the largest contiguous blocks of forest habitat in the region.

The forest ecosystems of the MAR include a diverse array of communities and species (Currie \& Paquin 1987). The diversity of trees provides the basis for the wide range of forested community types found in the MAR (Barbour \& Billings 1988). Forests of the MAR are dominated by oak-hickory communities and maple-beech-birch communities, and include pine and mixed pine- 
hardwood forests (McKenney-Easterling et al. 2000). In addition, locally important terrestrial ecosystems include shrublands that provide crucial habitat for wildlife, and communities such as limestone and dolomite glades that are home to endangered plant species. On the coastal plain, extensive stands of northern pine-oak forest (also known as pine barrens) form unique habitats for rare plants and animals.

Forest ecosystems are stressed by fragmentation, which occurs as humans subdivide forest plots into ever smaller and more isolated sections. Fragmentation can result in reduced genetic diversity within populations, losses of species, and increases in undesirable non-native and weedy species (Noss \& Csuti 1997). Large continuous forest patches exist in the region's southwestern area, but remaining forests in the region's urban corridor, Delmarva Peninsula, and the extreme eastern and western portions of Pennsylvania are heavily fragmented (J ones et al. 1997).

Ground level ozone and acid deposition (caused by $\mathrm{NO}_{x}$ and $\mathrm{SO}_{x}$ emissions from cars and power plants) stress forest trees (Likens et al. 1996), especially in Pennsylvania (J ones et al. 1997). Emissions have declined, and some areas are showing reduced levels of acid deposition (Schreiber 1995).

Forests are also threatened by the invasion of nonnative species. Non-native fungal diseases caused the effective extinction of 2 previously dominant trees, the American elm Ulmus americana and American chestnut Castanea dentata, and threaten a third, the butternut hickory J uglans cinerea (Schlarbaum et al. 1999). Insect pests such as gypsy moths Lymantria dispar and balsam wooly adelgids Adelges piceae can severely stress forests (Office of Technology Assessment 1993).

\subsection{Freshwater wetland ecosystems}

$M$ arshes and forested wetlands exist at the interface of terrestrial and aquatic ecosystems. Wetlands play a role in nutrient cycling, provide crucial fish and wildlife habitats, and remove pollutants from water (National Research Council 1995, Hammer 1997).

Several types of forested wetlands exist in the MAR. Northern swamp forests, dominated by red maple Acer rubrum, are widespread. Red spruce-balsam fir and bald cypress-black gum wetland forests are found in some locations. Seasonally flooded forests along streams and rivers contain a mix of species. The MAR is home to one of the most critically endangered ecosystems in the United States: more than $98 \%$ of the original stands of the distinctive Atlantic white-cedar Chamaecyparis thyoides swamp forest of the Great Dismal Swamp of Virginia and northern North Car- olina has been destroyed (N oss et al. 1995).

$\mathrm{N}$ on-forested wetlands or marshes in the region tend to be dominated by emergent plants such as cattails Typha. These marshes often form the transition between uplands and freshwater ecosystems and include several species of sedges and rushes (National Research Council 1995). Losses of lowland evergreen shrub bogs (pocosins) and montane sphagnum bogs have exceeded $85 \%$ in some states in the region (N oss et al. 1995).

Drainage (for agricultural and urban purposes) is the major threat to freshwater wetlands. Total losses for all wetland types vary across the region. For M aryland, it is estimated that between 1780 and $198073 \%$ of the original wetlands were drained (Noss et al. 1995). During the same period, approximately half of the wetlands in Pennsylvania and Virginia were destroyed, but losses were as low as $24 \%$ in West Virginia (Noss et al. 1995).

Additional threats to wetland ecosystems include pollution and non-native invasive species. High levels of chemical pollutants can accumulate in wetlands because pollutant carrying sediments are trapped in wetland vegetation. Non-native invasive species, such as the European plant purple loosestrife Lythrum salicaria, force out more beneficial native marsh plants.

\subsection{Freshwater ecosystems}

The importance of freshwater ecosystems to residents of the MAR is difficult to put into words, in part because of the deep attachments that many people have to streams, rivers and reservoirs in their communities. Freshwater resources have multiple, sometimes conflicting, values. These include fishing, swimming, boating, water supply, beauty, flood control, navigation and transportation, and hydropower. Freshwater ecosystems support aquatic plants and animals, as well as organisms in wetland and terrestrial ecosystems that depend upon freshwater. Downstream estuaries, such as the Chesapeake Bay, also depend on freshwater inflows.

The diversity of freshwater mussels in the Southeast, which includes southern portions of the MAR, is unmatched by any other area in the world (Williams \& Neves 1995). The number of mussel species historically known to occur ranges from 12 to 80 across the M AR's states, but the percentages at risk of extinction range from 46 to $71 \%$ (Williams \& Neves 1995). The number of native freshwater fishes range from 70 to 201 across these states, and the percentages of these fish estimated to be imperiled range from 3 to $12 \%$ (Warren \& Burr 1994).

Freshwater ecosystems, like terrestrial and wetland ecosystems, are stressed by habitat alteration, pollution and non-native invasive species. Stream habitat 
alterations include dams, road crossings, channelization, and loss of streambank vegetation. Dams are built to supply water for human uses, to control flooding, and to generate electricity. Dams also alter streamflow, sedimentation, temperature, and dissolved oxygen concentrations, impairing the ability of streams and rivers to support native fauna, especially freshwater fish and mussels. Dams occur in the highest densities in northeastern portions of the region and in southeastern Virginia; the largest electricity-producing structures are in mountainous areas (I ones et al. 1997).

Urban development diminishes the resilience of freshwater ecosystems to climate variability. Streamflows are moderated in vegetated watersheds because rain is absorbed into the ground and slowly released to streams. In contrast, in heavily paved urban areas, peak flows during storms are sharply increased, scouring stream banks, decreasing the reproductive success of aquatic insects and of fish that lay eggs near the edges of streams (Karr et al. 1986, Fisher et al. 1997). Streamflows during dry periods are likewise diminished, significantly reducing available habitat for fish and aquatic insects.

The replacement of forests and wetlands by urban and agricultural ecosystems generally increases the input of sediments, nutrients and toxic chemicals into rivers, streams, lakes and estuaries. Sediments reduce water clarity, smother bottom organisms, and clog waterways; excessive inputs of nutrients cause eutrophication, and toxic chemicals affect plants and animals. J ones et al. (1997) described the region's distribution of roads; agricultural, urban and forest land cover; land cover along stream banks; and areas with high potential for soil loss. Acid deposition and/or mine drainage are issues for about $3000 \mathrm{~km}$ of trout streams in Pennsylvania (Carline et al. 1992), and 93\% of 344 streams surveyed in western Virginia (Schreiber 1995).

Non-native invasive species, such as non-native fish and zebra mussels Dreissena polymorpha, are other important stresses. Non-native fish prey upon native species and/or outcompete them for available food or habitat, posing serious threats in some areas (Williams \& M effe 1998). Observations of zebra mussels in New York, Pennsylvania and West Virginia (US Geological Survey: http://nas.er.usgs.gov/zebra.mussel) show that these mussels are invading the MAR. Although their effects in the MAR are currently small, zebra mussels have had major impacts in areas near the MAR (e.g. Great Lakes region), suggesting the possibility of greater impacts in the future.

\subsection{C oastal ecosystems}

The coastal zone of the MAR harbors a series of distinct ecosystems with enormous recreational, commer- cial and aesthetic value. The Chesapeake Bay is the largest and most productive estuary in the United States (US EPA 1997). The Delaware Bay is an extremely important habitat for migratory shorebirds. Tidal salt marshes, occurring along the fringes of much of the coast, provide vital habitat for fish and wildlife and help to reduce the inputs of sediments, nutrients, and chemical pollutants from upland areas. Tidal marshes also help minimize damage from flooding, erosion, and storm surges.

The major threats to coastal ecosystems are habitat loss and pollution. Human development of coastal areas is associated with extensive loss of barrier island dunes, beaches and estuarine wetlands (Noss et al. 1995). Although 1.7 million acres ( $\sim 0.69$ million ha) of tidal and non-tidal wetlands still remain, over half of the original wetlands surrounding the Chesapeake Bay have been lost (Chesapeake Bay Program 1995a). Rising sea levels threaten many Chesapeake Bay communities. Historically, sea level has been increasing at rates of 3 to $4 \mathrm{~mm} \mathrm{yr}^{-1}$ in the MAR (Titus \& Narayanan 1995). Rising water levels threaten low-lying islands and change hydrologic and salinity characteristics of coastal wetlands. One-third of the Blackwater $\mathrm{N}$ ational Wildlife Refuge has been lost to sea-level rise in the last few decades (Climate Institute 1996a,b).

The greatest threat to the Chesapeake Bay (Chesapeake Bay Program 1995b) is eutrophication. Excessive nutrient inputs feed algae that block sunlight and reduce levels of dissolved oxygen in bottom waters when they die, sink and decompose. Submerged aquatic vegetation provides crucial habitat, but needs sunlight to grow. The combination of low oxygen conditions and reduced availability of submerged aquatic vegetation habitat seriously threatens fish, crabs and waterfowl. This problem is the motivation for a coordinated program to reduce nutrient inputs that has been in place since 1987 (US EPA 1997).

Other threats to the Chesapeake and Delaware Bays include over-harvesting of commercially valuable species, and loss of fish and shellfish to disease and toxic organisms. Oysters have not recovered from mass mortalities (losses $>75 \%$ ) in the 1980 s caused by 2 parasites: Perkinsus marinus and Haplosporidium nelsoni (US EPA 1998). These parasites, which cause Dermo and MSX, thrive in saline waters ( 15 to $30 \mathrm{ppt}$ ). Unusually warm and dry years resulted in the intrusion of saline waters further up the estuaries than usual, resulting in the devastating incidence of oyster disease. Pfiesteria-caused fish kills have been centered in the southeast part of the region, especially the Pamlico Sound in N orth Carolina (Burkholder et al. 1995). Pfiesteria develop from cysts into toxin-producing/fishkilling cells when conditions are right (warm water, high nutrient loads, moderate salinity, poor flushing 
and large numbers of fish present; US EPA 1998).

\section{HOW MIGHT CHANGES IN CLIMATE AND CLIMATE VARIABILITY EXACERBATE OR AMELIORATE CURRENT CONDITIONS?}

The following discussion of potential ecological responses to changes in climate and climate variability uses the Polsky et al. (2000) climate scenarios for the MAR, which are based on transient numerical models developed by the Hadley Centre for Climate Prediction and Research and the Canadian Climate Centre (CCC). These models project climate conditions for the next $100 \mathrm{yr}$, accounting for sulfate aerosols and a $1 \%$ $\mathrm{yr}^{-1}$ increase in carbon dioxide. Projections for sealevel rise are discussed in Najjar et al. (2000); compared to 1990, sea level is projected to rise 11 to $31 \mathrm{~cm}$ by 2030 and 41 to $103 \mathrm{~cm}$ by 2095. Historical climatic conditions in the M AR provide context for these potential future changes. Over the last $100 \mathrm{yr}$, average conditions have become warmer and wetter: average precipitation has gone up 10\% (linearly) and average temperature has risen by $1^{\circ} \mathrm{F}$. In the same period, the $M A R$ region has seen a decrease in the number of very hot days (i.e. temperatures above $90^{\circ} \mathrm{F}\left[\approx 32^{\circ} \mathrm{C}\right]$ ), and an increase in the number of very cold days (i.e. below $\left.0^{\circ} \mathrm{F}\left[\approx-18^{\circ} \mathrm{C}\right]\right)$. This section's discussion of ecological impacts is rather general, due to uncertainties regarding the rate, magnitude, spatial distribution, and sea- sonality of temperature and precipitation changes.

Changes in long-term climate patterns and climatic variability would have significant effects on natural ecosystems, but will have different, and in many ways greater, impacts on the already-stressed ecosystems of the MAR. The preceding discussion of forested, wetland, freshwater and coastal ecosystems emphasized the combined impacts of habitat degradation/loss/fragmentation, pollution and non-native species. This section explains how changes in climate and climate variability might affect ecosystems already weakened by these other stresses (e.g. following discussion and Table 1).

When conditions change, some species benefit and some aspects of ecosystem functioning are potentially enhanced. Still, a discussion of the 'benefits' of climate change for ecosystems is problematic. The focus of conservation science is on minimizing or reversing changes in ecosystem structure and functioning, in part because of the value people place on local and familiar species and communities (Hunter \& Hutchinson 1994). It is possible that timber productivity in the MAR could increase as a result of climatic changes, but it could take decades for the conditions underlying this projection to occur, and the new forests are likely to retain lower levels of native biodiversity due to the loss of some species that are unable to cope. Some species will become more abundant and widely distributed, as already seen in response to recent climate change

Table 1. The potential for adverse ecosystem impacts when changes in climate and climate variability interact with existing stresses

\begin{tabular}{|c|c|c|}
\hline Ecosystem & Existing stress & Interaction with climatic changes \\
\hline $\begin{array}{l}\text { Multiple } \\
\text { ecosystems }\end{array}$ & $\begin{array}{l}\text { Non-native invasive } \\
\text { species } \\
\text { UV-B, air pollution }\end{array}$ & $\begin{array}{l}\text { Climatic changes will probably tend to favor invasive species over rare and } \\
\text { threatened species } \\
\text { Adverse interactions with climatic changes (see text; Oppenheimer 1989) }\end{array}$ \\
\hline Forests & Fragmentation & $\begin{array}{l}\text { Fragmentation may hinder the migration of some species, and the loss of } \\
\text { genetic diversity within fragments will reduce the potential for populations } \\
\text { to respond to changing conditions through adaptive evolution (Peters \& } \\
\text { Darling 1985). }\end{array}$ \\
\hline Freshwater & Habitat loss & $\begin{array}{l}\text { Habitat loss reduces the resiliency of the MAR to the wetlands negative } \\
\text { effects of storms because wetlands play a role in moderating destructively } \\
\text { high Streamflows and pollution runoff }\end{array}$ \\
\hline \multirow[t]{3}{*}{ Freshwaters } & $\begin{array}{l}\text { Habitat degradation: } \\
\text { stream channelization }\end{array}$ & Straightening stream channels reduces their resiliency to destructively high flows \\
\hline & $\begin{array}{l}\text { Altered streamflow in } \\
\text { urban areas }\end{array}$ & $\begin{array}{l}\text { Increases in the frequency or intensity of storms could exacerbate this existing } \\
\text { problem }\end{array}$ \\
\hline & $\begin{array}{l}\text { Pollution: nutrients, } \\
\text { sediments, toxics }\end{array}$ & Increased precipitation could increase pollution runoff \\
\hline \multirow{3}{*}{$\begin{array}{l}\text { Coastal } \\
\text { ecosystems }\end{array}$} & Habitat loss & Accelerated sea-level rise could accelerate the loss of coastal wetlands \\
\hline & $\begin{array}{l}\text { Pollution: nutrients, } \\
\text { sediments, toxics }\end{array}$ & Increased precipitation could increase pollution runoff \\
\hline & $\begin{array}{l}\text { Disease and toxic } \\
\text { organisms }\end{array}$ & $\begin{array}{l}\text { Changes in temperature, precipitation and sea level may promote conditions } \\
\text { favorable to Dermo, MSX and Pfiesteria }\end{array}$ \\
\hline
\end{tabular}


(Alward et al. 1999, Parmesan et al. 1999, Thomas \& Lennon 1999). However, even some of these supposed benefits are likely to be reversed as expanding populations encounter new pathogens, parasites, competitors, and predators (Dukes \& Mooney 1999, Harvell et al. 1999). In addition, increases in species may not be beneficial if those that respond favorably to climate change are invasive, exotic species al ready considered pests (Dukes \& M ooney 1999).

It may be helpful to consider the ecological processes that determine how changes in climate and climate variability could affect ecosystem structure (e.g. which species are present, and in what abundances) and functioning. Environmental variables projected to change in the MAR include: carbon dioxide concentrations (increases are centain), temperature (increases are highly likely, but the distribution across space and time is uncertain), precipitation (projections are uncertain, increased frequency and intensity of severe storms and overall increases in precipitation are possible), sea level (already rising, highly likely to accelerate) and fires (predictions remain uncertain, Intergovernmental Panel on Climate Change [IPCC] 1996b).

Species may respond to changes in environmental variables by adapting, shifting their range, changing their abundance, or by disappearing altogether. Rapid evolution might help species with short generation times, such as insects and annual plants, to adapt to environmental changes (Rodríguez-Trelles et al. 1998). Evolution may be slower in long-lived species, such as trees (Mátyás 1997). Optimal climates for the MAR's dominant tree species in maple-beech-birch and oakhickory forest communities are predicted to shift to the north (Iverson \& Prasad 1998), while conditions for southern species such as longleaf and loblolly pine will become more favorable in the M AR (IPCC 1996a). Pest species may shift north or increase in abundance if temperatures increase. Shifts in fish species from cool and cold water species to warmer water species are likely (US EPA 1995). Species (or whole coastal wetland ecosystems, in the case of sea-level rise) could fail to shift their range if they cannot disperse fast enough to keep pace with change, if landscape features (such as cities) block their movement, or if new suitable habitats are simply not available (Pitelka and the Plant M igration Workshop Group 1997). A species may fail to colonize a prospective habitat if it cannot adapt to that habitat's soils or its level of human development, or if it cannot coexist with other species al ready in residence.

Invasive species share a set of traits that predispose them to successfully invade pre-existing communities (Dukes \& Mooney 1999). These traits include a high rate of population growth, which contributes to rapid colonization; ability to move long distances, which contributes to col onizing distant habitats; tolerance of close association with humans; and tolerance of a broad range of physical conditions (Rejmánek \& Richardson 1996). Since the traits of successful invaders tend to increase their resilience to a variety of disturbances, including climate and non-climate stresses, climate change could work in concert with other stresses to further reduce populations of rare and endemic species, while increasing populations of already abundant, widespread species (Dukes \& Mooney 1999). MAR residents would be unlikely to welcome the northward spread of problem species such as kudzu and the myriad of non-native species currently damaging ecosystems in Florida, such as melaleuca, brazilian pepper, and a variety of non-native freshwater fishes.

In addition to potentially exacerbating problems with non-native invasive species, changes in climate and climate variability might interact adversely with other existing stresses (see Table 1). Oppenheimer (1989) proposed that the concentrations of hydrogen peroxide-an oxidant that is toxic to terrestrial vegetation and to many aquatic organisms - in fog, precipitation and surface waters may increase due to the combined effects of increased temperature, UV-B, $\mathrm{NO}_{\mathrm{x}}$ and hydrocarbons. Increased levels of acidity and ground-level oxidants (including hydrogen peroxide) could degrade forests and watersheds and accelerate nutrient fluxes, leading to eutrophication of fresh- and coastal waters.

Stream channelization and wetland loss increase the MAR's vulnerability to precipitation changes. An increase in the frequency or intensity of storms could exacerbate existing problems. According to the IPCC (1998), increases in hydrological variability (larger floods and longer droughts) could result in increased sediment loading and erosion, degraded shorelines, reductions in water quality, and reduced stability of aquatic ecosystems, with the greatest impacts occurring in urban areas with a high percentage of impervious surface area. These changes may reduce productivity and biodiversity in streams and rivers (IPCC 1998). Increases in water temperature may lower dissolved oxygen concentrations, particularly in summer lowflow periods in mid-latitude areas (IPCC 1998). Altered precipitation and temperature patterns will affect the seasonal pattern and variability of water levels of wetlands, potentially affecting valued aspects of their functioning, such as flood protection, carbon storage, water cleansing, and waterfowl/wildlife habitat (IPCC 1998).

Inputs of nutrients and other pollutants into aquatic habitats will vary with rainfall and other characteristics of the watershed (M eyer \& Pulliam 1992). Farmers are likely to adapt to climate change (Abler \& Shortle 2000). Possible agricultural changes relevant to natural ecosystems include changes in the types of land cover and the use of toxic chemicals and fertilizers. Increases or decreases in agricultural pollution will thus depend 
upon both human responses to climate change and changes in runoff associated with altered precipitation patterns. Watershed responses to climate change are complex. One study (Band et al. 1996) found that incorporating the adjustment of canopy physiology in forested watersheds to elevated concentrations of carbon dioxide reduced the simulated impact of temperature and precipitation changes upon simulated fluxes of energy, water, carbon and nutrients.

Species will shift their geographic ranges at different rates, and some may be unsuccessful in reaching or colonizing new habitats. Since species will be affected differently by climatic changes, relationships among species will be altered. Ecosystem functions that depend upon interactions among species could be affected. The probability of ecosystem disruption and species extinction is positively related to the rate of climate change (IPCC 1998). Ecosystems are complex, and highly interconnected, making the effects of climate change extremely difficult to predict.

Losses of coastal wetlands are relatively easy to predict. Accelerated sea-level rise is likely and coastal wetlands are unlikely to be able to migrate inland quickly enough, particularly because the MAR's coast is heavily developed (Najjar et al. 2000). Changes in climate and climate variability would affect the Chesapeake and Delaware Bays via changes in temperature, sea level, precipitation, wind and water circulation patterns. Temperature is particularly important because it influences activity, feeding, growth, metabolism and reproduction. (See Najjar et al. 2000 for discussion of some of the consequences of climate change upon coastal ecosystems.) The incidence of 2 oyster diseases, Dermo and MSX, could increase if sea-level rise mimics saltwater intrusions caused in the mid1980s by unusually warm and dry years that resulted in mass mortalities of oysters. If summer precipitation increased and resulted in increased streamflow, it could have an ameliorating effect by reducing salinities. Fish kills caused by Pfiesteria tend to occur in warm water with high nutrient loads, moderate salinity and poor flushing (US EPA 1998). Harmful algal blooms caused by Aureococcus anopahagefferens are also sensitive to changing climate conditions and are favored by warm, saline, eutrophic waters (Beltrami 1989). Uncertainty in projections of climate and nutrient loading make it difficult to predict the future extent and magnitude of these problems.

\section{WHAT ARE THE POTENTIAL STRATEGIES FOR COPING WITH RISK AND TAKING ADVANTAGE OF NEW OPPORTUNITIES?}

Maintaining resilience in ecosystems is the primary objective of adaptation strategies to protect wildlife and habitats (IPCC 1996a, M arkham \& M alcolm 1996). Compared to other sectors, 'adaptation options for ecosystems are limited, and their effectiveness is uncertain' (IPCC 1998).

There is general agreement that humans already have overwhelming impacts on natural ecosystems (Vitousek et al. 1997) and that this interferes with the functioning of ecosystems in ways that are detrimental to our well being. A panel of 11 scientists (Daily et al. 1997) was 'certain' that 'ecosystem services are essential to civilization,' that 'human activities are already impairing the flow of ecosystem services on a large scale,' and that 'if current trends continue, humanity will dramatically alter virtually all of the earth's remaining natural ecosystems within a few decades.' The primary threats are: land-use changes that cause loss of biodiversity; disruption of carbon, nitrogen and other biogeochemical cycles; human-caused nonnative species invasions; releases of toxic substances; possible rapid climate change; and depletion of stratospheric ozone. This panel was 'confident that ... the functioning of many ecosystems could be restored if appropriate actions were taken in time' (Daily et al. 1997).

Attempts to take timely action to minimize climaterelated risks are hampered by: (1) the perception by some decision-makers that the impacts of climate change are distant and speculative and therefore do not warrant action, (2) the difficulty in making sitespecific predictions of future climate at a scale relevant to ecological processes (Root \& Schneider 1993), and (3) the global nature of climate change requiring large-scale efforts integrating local, regional, and national activities. It is increasingly unlikely that greenhouse gas emissions will be reduced quickly enough to fully prevent significant warming. Likewise, measures directed at specific effects of climate change are unlikely to be applied widely enough to protect the range of ecosystem services upon which society depends. Fortunately, reducing the impacts of non-climate stresses on ecosystems would also buffer ecosystems from negative effects of climate change. The range of potential strategies (Table 2 ) is broad enough to involve every resident of the MAR. Activities that conserve biological diversity, reduce fragmentation and degradation of habitat, and increase functional connectivity among habitat fragments will increase the ability of ecosystems to resist anthropogenic environmental stresses, including climate change (Markham \& Malcolm 1996, IPCC 1998, p. 279).

Challenges to the adoption of an effective strategy to address climate and non-climate related risks to ecosystems remain. Setting priorities among strategies 
Table 2. Strategies to increase resilience of ecosystems to climate change and other stressors. VOC: volatile organic compound

\begin{tabular}{|c|c|c|}
\hline Stressor & Strategy/human response & Examples \\
\hline \multirow[t]{2}{*}{ Physical habitat alteration } & - Conservation & $\begin{array}{l}\text {-Establish protected areas } \\
\text { - Protect natural features of managed } \\
\text { landscapes } \\
\text { - M inimize water consumption } \\
\text { (to protect aquatic habitats) }\end{array}$ \\
\hline & - Restoration & $\begin{array}{l}\text {-Examples to date include: } \\
\text { Long-leaf pine ecosystems } \\
\text { Everglades hydrology } \\
\text { Tall-grass prairie } \\
\text {-Manage species directly }\end{array}$ \\
\hline \multirow[t]{2}{*}{$\begin{array}{l}\text { Pollution (resulting in } \\
\text { eutrophication, acid deposition, } \\
\text { increased UV-B radiation, } \\
\text { other problems) }\end{array}$} & - Regulation of emissions & $\begin{array}{l}\text { - Control } \mathrm{SO}_{2}, \mathrm{NO}_{x} \text {, and volantine organic carbon } \\
\text { emissions from power plants and motor vehicles } \\
\text { - Regulate emissions of CFCs (e.g. M ontreal Protocol) } \\
\text { - Reduce point source water pollution }\end{array}$ \\
\hline & $\begin{array}{l}\text { - Regulation of land use and } \\
\text { non-point sources }\end{array}$ & $\begin{array}{l}\text { - Protect riparian buffers } \\
\text { - Change urban and agricultural practices }\end{array}$ \\
\hline \multirow[t]{2}{*}{ Non-native invasive species } & $\begin{array}{l}\text { - Prevention of introduction } \\
\text { and establishment }\end{array}$ & $\begin{array}{l}\text {-M onitor areas around ports of entry and eliminate } \\
\text { new populations }\end{array}$ \\
\hline & $\begin{array}{l}\text { - Management of established } \\
\text { populations }\end{array}$ & $\begin{array}{l}\text { - Release biological controls } \\
\text {-Eradicate invasive species }\end{array}$ \\
\hline \multirow[t]{3}{*}{ Global climate change } & $\begin{array}{l}\text { - Reduction of greenhouse gas } \\
\text { emissions }\end{array}$ & $\begin{array}{l}\text { - Reduce emissions from power plants and motor } \\
\text { vehicles } \\
\text {-Conserve energy }\end{array}$ \\
\hline & $\begin{array}{l}\text { - Reduction of climate impacts via } \\
\text { reduction of other stressors }\end{array}$ & $\begin{array}{l}\text {-Increase ecosystem resiliency to climate impacts } \\
\text { via habitat protection, reduced pollution, } \\
\text { control of invasive species }\end{array}$ \\
\hline & $\begin{array}{l}\text { - Direct reduction of climate } \\
\text { change impacts }\end{array}$ & $\begin{array}{l}\text {-Schedule dam releases to protect stream } \\
\text { temperatures } \\
\text {-Transplant species } \\
\text {-Establish migration corridors }\end{array}$ \\
\hline
\end{tabular}

is difficult, partly because so little is known about the effectiveness of alternative actions intended to reduce ecosystem vulnerability. Caution is needed in developing adaptive measures because lack of information and/or conflicting ecosystem goals can lead to maladaptation. For example, diverting hazardous pollutants from water to air or land may benefit aquatic ecosystems but cause problems in terrestrial ecosystems. Likewise, corridors connecting habitat fragments may help some species disperse but might also allow aggressive invasive species to enter fragile habitats (Simberloff et al. 1992).

Research that can help to reduce uncertainties is discussed in the next section, but we are still left with societal issues that need to be addressed. There is an urgent need for expanded dialogue so that societal priorities for ecosystem protection can be articulated. Public education, supported by ongoing research, is essential to inform the dialogue. Decisions need to be made with the understanding that the basis for deci- sions changes with increasing information.

\section{WHAT ARE THE POLICY-RELEVANT RESEARCH GAPS?}

The purpose of assessing the potential impacts of climate change upon ecosystems is to provide information to decision-makers and stakeholders about the consequences of possible actions. Research should be guided to meet these information needs. Crucial research gaps include:

- Ecosystem valuation. We need to improve our understanding of how society depends upon ecosystems and how people value different aspects of ecosystems. This information should be used in developing research priorities and in choosing among alternatives for increasing ecosystem resiliency.

- Ecosystem functioning. We still lack basic information about how ecosystems function, limiting our ability to predict and understand how changes in one 
part of an ecosystem affect other parts. Such changes include how current stresses, such as habitat loss and alteration, pollution, and non-native species are affecting ecosystems, and how these stresses could interact with climate change. The limits of our understanding are highlighted by the current difficulties in attempting to predict the ecological impacts of climate change.

- Monitoring. Indicators of the status of ecosystems, and the magnitude and distribution of stresses upon ecosystems, should be included in long-term ecological monitoring plans. Early warning signs of potential losses of valued ecosystem functions should be identified and included as indicators.

- M anagement options. Understanding the effectiveness of various management strategies is crucial to targeting limited resources for ecological protection. An example drawn from experiences with the Chesapeake Bay illustrates the value of these areas of research. Concern about declines in fish, crabs and waterfowl stimulated research into ecosystem function and human impacts, revealing the links between landuse practices, nutrient runoff, overgrowth of algae, loss of submerged aquatic vegetation and depressed levels of dissolved oxygen in bottom waters, and the animal declines. Ecological monitoring was essential to the discovery of these relationships, and to measuring the effectiveness of ongoing efforts to control inputs of nutrients to the Bay. Such experience can serve as a model to design an integrated research strategy for the other major types of MAR ecosystems likely to be sensitive to climate change.

Acknowledgements. We thank J oel Scheraga, Michael Slimak, Ann Fisher, Janet Gamble, Bill van der Schalie, Susan N orton, L. LaReesa Wolfenbarger, Terry Keating and 3 anonymous reviewers for comments on earlier versions of this manuscript. J.P.M . gratefully acknowledges the support of the American Association for the Advancement of Science and the US EPA's National Center for Environmental Assessment during the preparation of this manuscript. Note: The views expressed are the authors' own and do not represent official EPA policy.

\section{LITERATURE CITED}

Abler DG, Shortle J S (2000) Climate change and agriculture in the Mid-Atlantic Region. Clim Res 14:185-194

Alward RD, Detling J K, M ichunas DG (1999) Grassland vegetation changes and nocturnal global warming. Science 283:229-231

Band LE, Mackay DS, Creed IF, Semkin R, J effries D (1996) Ecosystem processes at the watershed scale: sensitivity to potential climate change. Limnol Oceanogr 41(5):928-938

Barbour M G, Billings WD (eds) (1988) North American terrestrial vegetation. Cambridge University Press, New York

Beltrami EJ (1989) Brown tide dynamics as a catastrophic model. In: Cosper EM et al. (eds) Novel phytoplankton blooms. Springer-Verlag, New York, p 307-315

Benson K, Kocagil P, Shortle J (2000) Climate change and health in the Mid-Atlantic Region. Clim Res 14:245-253

Burkholder J M, Glasgow HB J r, Hobbs CW (1995) Fish kills linked to a toxic ambush-predator dinoflagellate: distribution and environmental conditions. M ar Ecol Prog Ser 124: 43-61

Carline RF, Sharpe WE, Gagen CJ (1992) Changes in fish communities and trout management in response to acidification of streams in Pennsylvania. Fisheries 17:33-38

Chesapeake Bay Program (1995a) Chesapeake Bay: introduction to an ecosystem. Chesapeake Bay Program Headquarters, Annapolis, MD (accessed: August 1999); available at http://www.gmu.edu/bios/bay/cbpo/intro.htm

Chesapeake Bay Program (1995b) The state of the Chesapeake Bay. Chesapeake Bay Program Headquarters, US EPA, Annapolis, MD

Climate Institute (1966a) Conference brings together broad local group to explore impact of sea level rise on Chesapeake. Climate Alert 9(6), Climate Institute, Washington, DC (accessed: August 1999); available at: http://www.climate.org/ Climate-Alert/articles/9.6/index.html

Climate Institute (1996b) Changing climate, rising sea level, and Chesapeake Bay: questions and answers. Climate Institute, Washington, DC (accessed: August 1999); available at: http://www.climate.org/conferences/Chesapeake ConfStatement.html

Currie DJ, Paquin V (1987) Largescale biogeographical patterns of species richness of trees. Nature 329:326-327

Daily GC, Alexander S, Ehrlich PR, Goulder L, Lubchenco J , Matson PA, Mooney HA, Postel S, Schneider SH, Tilman D, Woodwell GM (1997) Ecosystem services: benefits supplied to human societies by natural ecosystems. Issues in Ecology No. 2. Ecological Society of A merica, Washington, DC

Dukes J S, Mooney HA (1999) Does global change increase the success of biological invaders? Trends Ecol Evol 14: 135-139

Fisher A, Barron E, Yarnal B, Knight CG, Shortle J (1999) Climate change impacts in the Mid-Atlantic Region-a workshop report, September 9-11, 1997. Pennsylvania State University, University Park

Hammer DA (1997) Creating freshwater wetlands, 2nd edn. CRC Lewis Publishers, Boca Raton, FL

Harvell CD, Kim K, Burkholder J M, Colwell RR, Epstein PR, Grimes DJ, Hofmann EE, Lipp EK, Osterhaus ADME, Overstreet RM, Porter JW, Smith GW, Vasta GR (1999). Emerging marine diseases-climate links and anthropogenic factors. Science 285:1505-1510

Hunter ML J r, Hutchinson A (1994) The virtues and shortcomings of parochialism: conserving species that are locally rare, but globally common. Conserv Biol 8: 1163-1165

Intergovernmental Panel on Climate Change (IPCC) (1998) The regional impacts of climate change: an assessment of vulnerability. Watson RT, Zinyowera MC, Moss RH (eds) Cambridge University Press, New York

Intergovernmental Panel on Climate Change (IPCC) Working Group II (1996a) Climate change 1995: impacts, adaptations and mitigation of climate change: scientific-technical analyses. Contribution of Working Group II to the Second Assessment Report of the Intergovernmental Panel on Climate Change. Watson RT, Zinyowera MC, Moss RH, Dokken DJ (eds). Cambridge University Press, New York

Intergovernmental Panel on Climate Change (IPCC) Working Group I (1996b) Climate Change 1995: the science of climate change. Contribution of Working Group I to the Sec- 
ond Assessment Report of the Intergovernmental Panel on Climate Change. Houghton J T, M eira Filho LG, Callander BA, Harris N, Kattenberg A, Maskell K (eds). Cambridge University Press, New York

Iverson LR, Prasad AM (1998) Predicting abundance of 80 tree species following climate change in the eastern United States. Ecol M onogr 68:465-485

J ones KB, Riitters KH, Wickham J D, Tankersley RD J r, O'N eill RV, Chaloud DJ , Smith ER, Neale AC (1997) An ecological assessment of the United States Mid-Atlantic region: a landscape atlas. US Environmental Protection Agency, EPA/600/R097/130, Washington, DC

Karr JR, Fausch KD, Angermier PL, Yant PR, Schlosser IJ (1986) Assessing biological integrity in running waters: a method and its rationale. III Nat Hist Surv Spec Publ 5

Likens GE, Driscoll CT, Buso DC (1996) Long-term effects of acid rain: response and recovery of a forest ecosystem. Science 272:244-246

Markham A, Malcolm J (1996) Biodiversity and wildlife: adaptation to climate change. In: Smith J B, Bhatti N, M enzhulin G, Benioff R, Budyko MI, Campos M, J allow B, Rijsberman $F$ (eds) Adapting to climate change, assessments and issues. Springer-Verlag, New York, p 384-398

Mátyás C (1997) Genetics and adaptation to climate change: a case study of trees. In: Huntley B et al. (eds) NATO ASI Series, Vol 147, Past and future rapid environmental changes: the spatial and evolutionary responses of terrestrial biota. Springer-Verlag, Berlin, p 357-370

McKenney-Easterling M, DeWalle DR, Iverson LR, Prasad AM, Buda AR (2000) The potential impacts of climate change and variability on forests and forestry in the MidAtlantic Region. Clim Res 14:195-206

Meyer J L, Pulliam WM (1992) Modification of terrestrialaquatic interactions by a changing climate. In: Firth $P$, Fisher SG (eds) Global climate change and freshwater ecosystems. Springer-Verlag, New York, p 177-191

Najjar RG and 15 others (2000) The potential impacts of climate change on the mid-Atlantic coastal region. Clim Res 14:219-233

National Research Council (1995) Wetlands: characteristics and boundaries. National Academy Press, Washington, DC

N oss RF, Csuti B (1997) Habitat fragmentation. In: M effe GK, Carroll CR (eds) Principles of conservation biology, 2nd edn. Sinauer Associates, Inc, Sunderland, M A, p 269-304

Noss RF, La Roe ET III, Scott J M (1995) Endangered ecosystems of the United States: a preliminary assessment of loss and degradation. Biological Report 28. US Department of the Interior, National Biological Service, Washington, DC

Office of Technology Assessment (OTA) (1993) Harmful nonindigenous species in the United States, OTA-F-565. US Congress, US Government Printing Office, Washington, DC

Oppenheimer M (1989) Climate change and environmental pollution: physical and biological interactions. Clim Change 15:255-270

Parmesan CN, Ryrholm C, Stefanescu J K, J ill CD, Thomas H, Descimon B, Huntley L, Kaila J , Kullberg T, Tammaru WJ , Tennet J A, Warren T, Warren M (1999) Poleward shifts in geographical ranges of butterfly species associated with regional warming. Nature 399:579-583

Peters RL, Darling JDS (1985) The greenhouse effect and nature reserves. Bioscience 35:707-717

Pitelka LF and the Plant Migration Workshop Group (1997) Plant migration and climate change. Am Sci 85:464-473

Polsky C, Allard J, Curritt N, Crane R, Yarnal B (2000) The Mid-Atlantic Region and its climate: past, present, and future. Clim Res 14:161-173
Rejmánek M, Richardson DM (1996) What attributes make some plant species more invasive? Ecology 77:1655-1661

Rodríguez-Trelles F, Rodríguez MA, Scheiner SM (1998) Tracking the genetic effects of global warming: Drosophila and other model systems. Conserv Ecol [online] 2(2):2, Ecological Society of America, Washington, DC (accessed: August 1999); available at http://www.consecol.org/vol2/iss2/art2

Root TL, Schneider SH (1993) Can large-scale climatic models be linked with multiscale ecological studies? Conserv Biol $7: 256-270$

Rose A, Cao Y, Oladosu G (2000) Simulating the economic impacts of climate change in the Mid-Atlantic Region. Clim Res 14:175-183

Schlarbaum SE, Hebard F, Spaine PC, Kamalay JC (1999) Three American tragedies: chestnut blight, butternut canker, and Dutch elm disease. USDA Forest Service, Southeastern Research Station, Asheville, NC

Schreiber K (1995) A cidic deposition. In: La Roe ET, Farris GS, Puckett CE, Doran PD, M ac MJ (eds) Our living resources: a report to the nation on the distribution, abundance, and health of US plants, animals, and ecosystems. US Department of the Interior, National Biological Service, Washington, DC, p 418-420

Simberloff DJ , Farr A, Cox J , M ehlman DW (1992) M ovement corridors: conservation bargains or poor investments? Conserv Biol 6:493-504

Thomas CD, Lennon JJ (1999) Birds extend their ranges northwards. Nature 399:213

Titus J G, Narayanan VK (1995) The probability of sea-level rise. US Environmental Protection Agency, EPA 230-R-95008, Washington, DC

US Environmental Protection Agency (1995) Ecological impacts from climate change: an economic analysis of freshwater recreational fishing. US EPA, EPA 230-R-96-004, Washington, DC

US Environmental Protection Agency (1997) Chesapeake Bay nutrient reduction progress and future directions. US EPA, EPA 903-R-97-030, Washington, DC

US Environmental Protection Agency (1998) Condition of the Mid-Atlantic estuaries. Office of Research and Development, US EPA, EPA 600-R-98-147, Washington, DC

US Environmental Protection Agency (1999) Terms of environment. US EPA, Washington, DC (accessed: February 1999); available at http://www.epa.gov/OCEPAterms/

US National Assessment (1997) US Climate Forum: the consequences of global change for the nation. US Department of Commerce, Washington, DC, November 12-13, 1997 (accessed: August 1999); available at http://www.nacc. usgcrp.gov/meetings/forum/

Vitousek PM, M ooney HA, Lubchenco J, Melillo J M (1997) Human domination of earth's ecosystems. Science 277: 494-499

Warren ML, Burr BM (1994) Status of freshwater fishes of the United States: overview of an imperiled fauna. Fisheries 19(1):6-18

Williams J D, M effe GJ (1998) Nonindigenous species. In: M ac MJ , Opler PA, Puckett Haecker CE, Doran PD (eds) Status and trends of the nation's biological resources. US Department of the Interior. US Geological Survey, Reston, VA, p 117-129.

Williams J D, Neves RJ (1995) Freshwater mussels: a neglected and declining aquatic resource. In: La Roe ET, Farris GS, Puckett CE, Doran PD, Mac MJ (eds) Our living resources: a report to the nation on the distribution, abundance, and health of US plants, animals, and ecosystems. US Department of the Interior, National Biological Ser- 